\title{
Etika dan Kompetensi Konselor Sebagai Profesional (Suatu Pendekatan Literatur Sistematis)
}

\author{
Happy Karlina Marjo, Darojaturroofi'ah Sodiq * \\ Program Studi Magister Bimbingan dan Konseling, Fakultas Ilmu Pendidikan, \\ Universitas Negeri Jakarta \\ *Corresponding Author. Email: darojaturroofiahsodiq_1108820002@mhs.unj.ac.id
}

\begin{abstract}
The purpose of this study was to describe the ethics and competence of counselors as professionals in providing guidance and counseling services. The research method used is a systematic literature study. This systematic literature review contains explanations and descriptions of theories, findings and research materials obtained from databases of national and international journal providers through the Google Scholar platform, and then analyzed descriptively. The result of this research is that ethics and competencies must be possessed by a counselor as the basis for the profession he adheres to. Counselor education is one way to develop competencies for prospective counselors. The competence of the counselor as an agent for counseling guidance services is stated in government regulation No. 19 of 2005 article 28 paragraph 3, namely: competence as a service agent at the level of primary and secondary education and early childhood education which includes pedagogic competence, personality, professional and social competence. Professional counselors must have a strong determination to be able to help others and have a positive nature to be able to view the counselee as a human being who has different values, religious teachings, cultures and backgrounds.
\end{abstract}

\begin{abstract}
Abstrak: Tujuan penelitian ini adalah untuk mendeskripsikan etika dan kompetensi konselor sebagai professional dalam memberikan layanan bimbingan dan konseling. Metode penelitian yang digunakan adalah studi literature sistematis. Kajian literatur sistematis ini berisikan tentang penjelasan dan uraian teori, temuan dan bahan penelitian yang didapatkan dari database penyedia jurnal nasional dan internasional melalui platform google scholar, dan selanjutnya di analisis secara deskriptif. Hasil penelitian ini adalah etika dan kompetensi harus dimiliki seorang konselor sebagai dasar atas profesi yang dianutnya. Pendidikan konselor merupakan salah satu cara untuk mengembangkan kompetensi bagi para calon konselor. Kompetensi konselor sebagai agen pelayanan bimbingan konseling, dinyatakan dalam peraturan pemerintah No 19 tahun 2005 pasal 28 ayat 3 yaitu: kompetensi sebagai agen pelayanan pada jenjang pendidikan dasar dan menengah serta pendidikan anak usia dini yang meliputi kompetensi pedagogik, kepribadian, profesional dan kompetensi sosial. Konselor profesional harus memiliki tekad yang kuat untuk dapat membantu orang lain dan memiliki sifat positif untuk dapat memandang konseli sebagai manusia yang memiliki nilai-nilai, ajaran agama, budaya dan latar belakang yang berbeda.
\end{abstract}

How to Cite: Marjo, H., \& Sodiq, D. (2022). Etika dan Kompetensi Konselor Sebagai Profesional (Suatu Pendekatan Literatur Sistematis). Jurnal Paedagogy, 9(1), 86-93. doi:https://doi.org/10.33394/jp.v9i1.4512 do) https://doi.org/10.33394/jp.v9i1.4512

This is an open-access article under the CC-BY-SA License.
Article History

Received: 30-11-2021

Revised: 13-12-2021

Accepted: 20-12-2021

Published: 07-01-2022

\section{Key Words:}

Ethics, Competence, Professional Counselor.

\section{Sejarah Artikel}

Diterima: 30-11-2021

Direvisi: 13-12-2021

Disetujui: 20-12-2021

Diterbitkan: 07-01-2022

\section{Kata Kunci:}

Etika, Kompetensi, Konselor Profesional.

\section{Pendahuluan}

Konseling merupakan layanan profesional yang memanfaat-kan hubungan antar individu. Hubungan yang bersifat membantu itu harus lurus dengan memegang etika antar manusia. Karena itu, hubungan tersebut harus dilindungi dari perilaku yang salah dari pihak konselor, klien maupun masyarakat. Perlindungan itu pada umumnya ditata dalam bentuk 
kode etik (Suherman, 2007). Nilai-nilai dan etika sangat berhubungan, karena etika seorang individu dan kelompok mencerminkan nilai mereka. Bixler \& Seaman (Beck, 1971) menyatakan bahwa " etika merupakan prinsip-prinsip dari suatu tindakan yang berdasarkan sistem nilai yang biasa berlaku di suatu tempat. Karena itu tuntutan bagi seorang konselor adalah memaknai hakekat konseling dengan menunjukkan sikap profesionalisme yang konsisten dengan nilai-nilai yang ada dan berlaku di masayarakat.

Profesionalisme adalah paham yang mengajarkan bahwa setiap pekerjaan harus dilakukan oleh orang yang profesional (Rakhmawati, 2013). Orang yang profesional adalah orang yang memiliki profesi. Seseorang disebut memiliki profesi bila ia memenuhi kriteria berikut: 1). Profesi harus mengandung keahlian, artinya suatu profesi itu harus ditandai oleh suatu keahlian yang khusus profesi itu. Keahlian itu diperoleh dengan cara mempelajarinya secara khusus karena profesi bukan diwarisi. 2). Profesi dipilih karena panggilan hidup dan dijalani sepenuh waktu. Profesi dipilih karena dirasakan sebagai kewajiban, sepenuh waktu maksudnya bukan part time. 3). Profesi memiliki teori-teori yang baku secara universal, artinya profesi itu dijalani menurut aturan yang jelas, dikenal umum, dan teorinya terbuka. Secara universal pegangannya itu diakui. 4). Profesi adalah untuk masyarakat, bukan untuk diri sendiri. 5). Profesi harus dilengkapi dengan kecakapan dan kompetisi aplikatif. Kecakapan dan kompetesi itu diperlukan untuk meyakinkan peran profesi itu terhadap kliennya. 6). Profesi memiliki otonomi dalam melakukan tugas profesinya. Otonomi itu hanya dapat ditinjau dan dinilai oleh rekan-rekannya seprofesi. 7). Profesi memiliki kode etik yang disebut kode etik profesi. 8). Profesi harus memiliki klien yang jelas, yaitu orang yang membutuhkan layanan (Muhibbin, 1995)

Etika profesi merupakan salah satu aspek yang menjadi standarisasinya profesi bimbingan konseling sebagai sebuah kesepakatan yang mengacu pada perilaku etis. Sebagai seorang guru bimbingan dan konseling tidak bisa lepas dari nilai-nilai dan etika yang berlaku atas dasar nilai yang dianutnya, maka kegiatan layanan bimbingan dan konseling yang diberikan dapat berlangsung dengan arah dan tujuan yang jelas (Suherman, 2007). Etika dan kompetensi harus dimiliki seorang konselor sebagai dasar atas profesi yang dianutnya.

Standar kompetensi, merupakan ukuran kemampuan minimal yang mencakup kemampuan, pengetahuan, keterampilan, dan sikap yang harus diketahui, dicapai dan mahir dilakukan oleh tenaga konselor. Kompetensi konselor sebagai agen pelayanan bimbingan konseling, yang dinyatakan dalam peraturan pemerintah No 19 tahun 2005 pasal 28 ayat 3 yaitu: kompetensi sebagai agen pelayanan pada jenjang pendidikan dasar dan menengah serta pendidikan anak usia dini yang meliputi kompetensi pedagogik, kepribadian, profesional dan kompetensi sosial (Fadhila Yusri, 2013)

Pendidikan konselor merupakan salah satu cara untuk mengembangkan kompetensi bagi para calon konselor. Dalam hal ini perguruan tinggi penyelenggara pendidikan bimbingan konseling memiliki peran penting. Pada masa menempuh pendidikan inilah para calon konselor ditempa untuk menjadi konselor profesional yang memiliki semua kompetensi yang diharuskan. Selama masa pendidikan calon konselor diberikan wawasan, pengetahuan, keterampilan, nilai dan sikap yang harus dikuasainya sebagai konselor yang profesional (Fadhilla Yusri, 2019).

Kompetensi profesional merupakan seperangkat keterampilan yang harus dikuasai oleh konselor untuk menjadi sosok yang professional. Kompetensi professional ini adalah salah satu dari 4 standar kompetensi yang harus dimiliki oleh konselor (Permendiknas no. 27, 2008). Kompetensi profesi konselor merupakan keterpaduan kemampuan personal, keilmuan 
dan teknologi, serta sosial yang secara menyeluruh membentuk ke-mampuan standar profesi konselor (Fadhilla Yusri, 2019).

Dalam hubungan kerja antara konselor dan klien yang sedang dibina haruslah memiliki batas-batas tanggung jawab masing-masing sebagai hubungan professional agar proses konseling berjalan dengan baik (Abdillah, Kurniawati, 2021) Kode Etik ACA (Counseling, 2014) membahas beberapa hubungan antara konselor sekolah, pengawas, siswa, dan pembimbing serta menerapkan istilah interaksi dan hubungan nonprofesional untuk membedakan hubungan yang terjadi di luar dunia professional. Menjadi guru bimbingan konseling diperlukan untuk dapat profesional dalam pekerjaannya, sebagai professional harus memiliki keinginan kuat untuk menolong orang lain dan memiliki sifat yang positif dalam memandang konseli yang memiliki banyak keragaman (Prakoso, 2008).

Konselor profesional menurut Permendiknas nomor 27 Tahun 2008, selain harus memiliki kualifikasi akademik yang sesuai juga harus memiliki empat kompetensi utama, yaitu pedagogik, pribadi, sosial, dan profesional. Terkhusus untuk kompetensi profesional, konselor sekolah dituntut untuk menguasai konsep praksis asesmen, menguasai kerangka teoretik dan praksis bimbingan dan konseling, merancang program bimbingan dan konseling, mengimplementasikan program BK komprehensif, menilai proses dan hasil kegiatan bimbingan dan konseling, memiliki kesadaran dan komitmen terhadap etika professional, dan menguasai konsep dan praktis penelitian dalam bimbingan dan konseling (Haryadi, 2019).

Keprofesionalan seorang Guru Bimbingan Konseling harus tetap terjaga, artinya kahlian yang telah dimiliki itu tidak boleh berkurang apalagi hilang. Jika ini yang terjadi maka akan sangat berisiko yakni merugikan peserta didik atau konseli yang mendapatkan layanan darinya (Sodiq \& Herdi, 2021: Sari \& Herdi, 2021: Hardika \& Herdi, 2021) . Guru Bimbingan Konseling harus berusaha dengan berbagai macam cara agar keahlian yang telah dikuasai tetap standar bahkan kalau bisa lebih meningkat. Karena itulah maka adanya upaya untuk pengembangan professional (Widada, 2019). Adapun tujuan penelitian ini adalah untuk mendeskripsikan etika dan kompetensi konselor sebagai professional dalam memberikan layanan bimbingan dan konseling.

\section{Metode Penelitian}

Metode penelitian yang digunakan adalah metode kajian literatur sistematis. Kajian literatur sistematis ini berisikan tentang penjelasan dan uraian teori, temuan dan bahan penelitian yang didapatkan dari bahan acuan yang dijadikan landasan penelitian. Bagian metode ini membahas tentang strategi pencarian jurnal yang akan digunakan dalam kajian literatur sistematik. Artikel yang digunakan dalam kajian literatur sistematik ini didapatkan melalui dtabase penyedia jurnal nasional dan internasional melalui platform google scholar. Muncul dengan 17.600 temuan, kemudian di urutkan menurut relevansi tahun terbaru. Hal lain yang relevan, menggunakan semua penelitian dalam mengidentifikasi etika dan kompetensi konselor sebagai profesional. Selanjutnya data yang diperoleh dianalisis secara deskriptif.

\section{Hasil Penelitian dan Pembahasan}

Mendiskusikan tentang etik menyangkut masalah baik dan buruk. Etik merupakan pedoman, hubungan dan nilai bagi masyarakat. Etik akan menjadi pedoman untuk membangun belief system dan bagaimana pengaruhnya terhadap orang lain. Prinsip-prinsip etik bersumber dari filsafat moral yang menekankan pada pembuatan keputusan berdasarkan pada pertimbangan moral (Sanyata, 2006). Kode etik konselor mengatur anggota profesi untuk memakai dasar-dasar pertimbangan moral dalam layanan konseling, pada satu sisi kode 
etik juga memperkuat aturan hukum bagi anggota yang tidak selaras dengan kode etik konselor. Diperlukannya aturan hukum karena dalam moralitas dan etik tidak mengatur sangsi bagi siapapun yang melakukan perbuatan-perbuatan buruk. Aturan hukum (kode etik) merupakan alat yang dipakai untuk memberikan jaminan kepastian hukum terhadap anggota profesi yang melakukan aktivitas profesinya tidak sesuai dengan moralitas dan prinsip-prinsip nilai (Corey, 2011).

Pertimbangan etis dan moral menjadi dasar bagi konselor untuk melakukan berbagai aktivitas yang terkait dengan profesinya. Dalam interaksi konseling dengan masalah standar moral yang dimiliki antara konselor-klien tidak jarang berbeda bahkan dapat bertentangan. Keadaan ini menuntut konselor memakai belief system yang terbentuk untuk memfasilitasi dan membantu klien (Sanyata, 2006). Hal-hal yang terkait dengan prinsip nilai yang terbangun dalam konselor adalah konselor memiliki respek terhadap kemandirian klien, konselor menjadi "orang baik" bagi kliennya, dan memiliki ketulusan dalam memberikan bantuan kepada mereka (klien). Sedangkan hal-hal yang berkaitan dengan hakekat nilai adalah konselor memiliki integritas kepribadian yang mampu menjadi teladan bagi kliennya, konselor memiliki kesadaran bahwa profesi dan layanan yang diberikan bergantung pada dimensi sosial sehingga ada tanggung jawab moral terhadap masyarakat, konselor memiliki kemampuan penerimaan secara emosional kepada kliennya dan konselor mempunyai self awareness terhadap potensi dan kemampuan dirinya (Haolah dkk., 2018).

Prinsip Etika adalah seperangkat kewajiban dan metode yang berfokus pada masalah moral dengan tujuan (a) memecahkan dilema tertentu atau serangkaian dilema dan (b) menetapkan kerangka kerja untuk memandu pemikiran dan perilaku etis di masa depan. Menurut Asosiasi Konseling Kanada (CCA, 2007), pendekatan etika kebajikan didasarkan pada keyakinan bahwa konselor termotivasi untuk berbudi luhur dan peduli karena mereka percaya itu adalah hal yang benar untuk dilakukan. Kebajikan etika menekankan tanggung jawab konselor dalam membuat keputusan etis yang kompleks (Corey, 2011).

Konselor profesional akan memperhatikan kinerjanya untuk selalu mengutamakan kesejahteraan konseli dan kepercayaan masyarakat. Sistem nilai yang diyakini konselor merupakan penentu dalam perilaku etis (Hunainah, 2016). (Wilcoxon et al., 2007 ; Gladding, 2012) menuliskan lima prinsip etik yang berhubungan dengan aktivitas dan pilihan etik konselor, yaitu:

1). Benefience/perbuatan baik artinya melakukan yang baik dan mencegah kerugian.

2). Nonmaleficence artinya tidak mengakibatkan kerugian/rasa sakit.

3). Autonomy/otonom artinya memberikan kebebasan dalam memilih dan pengambilan keputusan sendiri.

4). Justice/adil.

5). Fidelity/kesetiaan artinya berpegang teguh pada komitmen.

Dalam Kode Etik ACA (2005) hubungan konseling ditempatkan pada bagian pertama dari delapan bagian isi Kode Etik. Dalam Kode Etik Bimbingan dan Konseling, baik Kode Etik ACA maupun ABKIN secara jelas telah berusaha memberikan batas-batas etis hubungan profesional. Sependapat dengan Geldard \& Geldard bahwa dalam hubungan apapun yang kita jalani, kita selalu menentukan batasan-batasan. Kita masing-masing memiliki garis batas di sekitar diri kita untuk melindungi identitas kita sebagai seorang individu. Kekuatan dari batas tersebut dan karakteristiknya bergantung pada dengan siapa kita menjalin hubungan dan konteks hubungan tersebut.

Hubungan konseli dan konselor adalah tipe hubungan yang istimewa, yang dibangun oleh konseli untuk satu tujuan. Konseli melibatkan diri dalam sebuah hubungan di mana ia 
memberi kepercayaan kepada konselor mereka dan dalam perjalanan hubungan tersebut, konseli berharap pada konselor dapat membantu menyelesaikan permasalahannya (Geldard, 2005). Bond (2000) dalam Nelson-Jones (2012) mengusulkan enam sumber etika bimbingan dan konseling yaitu : (1) etika personal, (2) etika dan nilai-nilai yang implisit di dalam modelmodel terapeutik, (3) kebijakan agency, (4) kode dan pedoman profesional, (5) filosofi moral dan (6) hukum.

Kompetensi konselor telah dikembangkan dan dirumuskan menjadi empat kompetensi pendidik sebagaimana yang tertuang dalam PP 19/2005 yang dipetakan menjadi kompetensi pedagogik, kepribadian, sosial, dan profesional (Ernawati., 2020). Chaplin mengartikan bahwa kompetensi adalah, kecakapan, kemampuan, dan wewenang. Dan kompetensi terjemahan dari kata competence yang artinya kelayakan kemampuan atau pelatihan untuk melakukan satu tugas (Chaplin, 2004). Kompetensi konselor muncul ketika konselor menerima sebuah posisi sebagai konselor profesional, apakah ia mempunyai kualifikasi sesuai dengan pendidikan, pelatihan dan pengalaman untuk mengemban posisi tersebut . Untuk itu, sejak awal konselor tidak boleh memaksakan dirinya menempati posisi tersebut jika ia tidak berminat atau tidak mempunyai kualifikasi (Gibson \& Mitchell, 2008).

Bersikap terus terang terhadap keterbatasan profesional dan pribadi bukan perkara mudah. Sikap tersebut hanya muncul pada konselor yang mempunyai tanggung jawab profesional yang tinggi dan komitmen yang kuat untuk menempatkan kesejahteraan konseli di atas kepentingan lembaga dan pribadi. Imbalan materi seperti menerima pembayaran atas jasa layanan konseling bagi lembaga dan atau pribadi konselor hendaknya tidak mengabaikan kesejahteraan konseli. Pertimbangan etik ini penting, seiring dengan berkembang pesat kebutuhan layanan konseling seting kemasyarakatan saat ini yang memungkinkan munculnya beragam layanan konseling di satu sisi, dan masih minimnya ketersediaan konselor profesional yang memiliki banyak keahlian atau konselor spesialis (Hunainah, 2016).

Gibson dan Mitchell (2008) menjelaskan bahwa dalam kerjanya, konselor bertanggungjawab secara profesional untuk berpraktik dalam batas-batas kemampuannya. Memang tidak mudah menentukan batas-batas kompetensi konselor, namun pelatihan dan pengalaman dapat menyediakan sebuah garis pedoman yang bermanfaat untuk mengindikasikan apakah konselor mempunyai kualifikasi atau tidak. Berkonsultasi pada superviser dan atau kolega profesional yang lebih berpengalaman dapat membantu konselor mengidentifikasikan batas-batas kompetensi profesionalnya (Suharni \& Christiana, 2020).

Dalam Dalam Naskah Akademik, sosok utuh kompetensi konselor terdiri atas 2 komponen yaitu:

a) Kompetensi akademik konselor profesional terdiri atas : (1)Kemampuan mengenal secara mendalam konseli yang hendak dilayani dengan memiliki kemampuan intelegensi dan kemampuan berpikir, motivasi dan keuletan, kreatif, arif. (2). Memiliki kepemimpinan, sikap empatik, menghormati keragaman (3). Mengedepankan masalah konseli dengan menguasai secara akademik teori, prinsip, teknik dan prosedur dan saran pelayanan bimbingan dan konseling dan mengemas semuanya dalam menyelenggarakan pelayanan bimbingan dan konseling yang memandirikan (4). Menyelenggarakan layanan ahli bimbingan dan konseling yang memandirikan dengan merancang, mengimplementasikan, menilai proses dan hasil serta mengembangkan profesionalitas sebagai konselor.

b) Kompetensi profesional konselor melalui : (1). Latihan Program Pengalaman Lapangan (PPL) yang sistematis dan sungguh-sungguh mulai dari observasi, dalam rangka pengenalan lapangan. (2). Latihan keterampilan dasar penyelenggaraan 
konseling (3). Latihan terbimbing kemudian meningkat menjadi latihan melalui penugasan terstruktur (4). Latihan mandiri dalam program pemagangan di bawah pengawasan Dosen Pembimbing.

Selain keberadaan kompetensi konselor yang dijadikan landasan bagi pengembangan konselor yang profesional, latar belakang pendidikan juga merukan hal yang penting dalam membentuk konselor yang profesional. Konselor profesional merupakan seperangkat perilaku nyata yang ditunjukkan oleh seorang konselor profesional dalam melaksanakan tugas atau pekerjaan profesional atau keahliannya. Tinggi dan rendahnya kualitas profesional seorang konselor akan berdampak langsung terhadap tinggi dan rendahnya pengakuan masyarakat luas dan imbalan yang akan diterimanya (Putri, 2016). Dengan kata lain, seorang konselor profesional akan selalu menjaga kualitas kinerja dan nama baik pribadi dan profesinya.

Beberapa aspek yang terkandung dalam konsep kompetensi menurut Gordon (Taher et al., 2021) adalah; pengetahuan (knowledge), pemahaman (understanding), kemampuan (skill), nilai (value), sikap (attitude), dan minat (interest). Aspek-aspek tersebut kemudian dijelaskan lebih lanjut sebagai berikut:

a) Pengetahuan (knowledge); yaitu kesadaran dalam bidang kognitif, misalnya seorang guru BK mengetahui cara melakukan identifikasi kebutuhan peserta didik.

b) Pemahaman (understanding); yaitu kedalaman kognitif dan afektif yang dimiliki oleh individu. Misalnya seorang guru BK yang akan melaksanakan layanan bimbingan konseling harus memiliki pemahaman yang baik terhadap karakteristik dan kondisi peserta didik agar dapat melaksanakan layanan secara efektif dan efisien.

c) Kemampuan (skill) merupakan sesuatu yang dimiliki oleh individu untuk melaksanakan tugas atau pekerjaan yang dibebankan kepadanya. Misalnya kemampuan guru BK dalam memilih dan melatihkan konten cara belajar efektif untuk meningkatkan kualitas belajar peserta didik.

d) Nilai (value); Suatu standar perilaku yang telah diyakini dan secara psikologis telah menyatu dalam diri seseorang. Misalnya standar perilaku guru bimbingan konseling dalam memberikan layanan konseling seperti mampu menjaga rahasia, terbuka, dan jujur.

e) Sikap (attitude); Perasaan (senang-tidak senang, suka-tidak suka) atau reaksi terhadap suatu rangsangan yang datang dari luar.

f) Minat (interest); adalah kecenderungan seseorang untuk melakukan suatu perbuatan. Misalnya minat untuk melakukan sesuatu.

Guru BK/konselor merupakan sebuah profesi professional. Sebagai sebuah profesi, guru BK memiliki sebuah etika profesi. "Etika profesi bimbingan dan konseling adalah kaidah-kaidah perilaku yang menjadi rujukan bagi konselor dalam melaksanakan tugas atau tanggung jawabnya memberikan pelayanan bimbingan dan konseling kepada konseli (Supriatna, 2011).

\section{Kesimpulan}

Kesimpulan yang diperoleh dari studi literatur sistematis ini bahwa etika dan kompetensi harus dimiliki seorang konselor sebagai dasar atas profesi yang dianutnya. Pendidikan konselor merupakan salah satu cara untuk mengembangkan kompetensi bagi para calon konselor. Kompetensi konselor sebagai agen pelayanan bimbingan konseling, dinyatakan dalam peraturan pemerintah No 19 tahun 2005 pasal 28 ayat 3 yaitu: kompetensi sebagai agen pelayanan pada jenjang pendidikan dasar dan menengah serta pendidikan anak 
usia dini yang meliputi kompetensi pedagogik, kepribadian, profesional dan kompetensi sosial.

Konselor profesional harus memiliki keinginan dan tekad yang kuat untuk dapat membantu orang lain dan memiliki sifat positif untuk dapat memandang konseli sebagai manusia yang memiliki nilai-nilai, ajaran agama, budaya dan latar belakang yang berbeda. Konselor haruslah memiliki tanggung jawab sepenuhnya, mampu untuk mengontrol diri, memiliki keseimbangan emosi, dan kesadaran penuh terhadap perbedaan nilai, agama, budaya dan keyakinannya. Serta sebagai konselor profesional harus dapat memenuhi kualifikasi sebagai konselor dengan baik, agar dapat membantu menangani konseli dengan baik. Pengetahuan, pemahaman, kemampuan, nilai, sikap dan minat yang konselor miliki menjadi sebuah benteng utama yang dimiliki agar tidak menimbulkan kesalahpahaman dengan posisi dan keadaan konseli. Dengan kompetensi yang dimiliki akan membuat konselor semakin paham tentang dirinya dan juga konseli.

\section{Saran}

Disarankan kepada para konselor untuk dapat menjunjung tinggi etika profesi dan harus mengacu pada kode etik bimbingan dan konseling yang menjelaskan tentang kompetensi profesional. Serta untuk meningkatkan kompetensi profesional konselor untuk ikut serta dalam kegiatan kelembagaan untuk meningkatkan ilmu pengetahuan dibidang bimbingan dan konseling

\section{Daftar Pustaka}

Abdillah, Kurniawati, M. (2021). Pelaksanaan Kode Etik Konselor dalam Hubungan Ganda di Sekolah. Jurnal Ilmiah Bimbingan Konseling Undiksha, 12(1), 21-30. https://doi.org/10.23887/XXXXXX-XX-0000-00.

ASCA. Ethical Standard for School Counselor. Journal of The School Counselor,32,84-87.

Chaplin, J.P., (2004). Kamus Lengkap Psikologi. Judul asli Dictionary of Psychology diterjemahkan Kartini Kartono, Jakarta: PT. Raja Grafindo Persada, h. 99

Corey, G., Corey, M.S.., \& Callanan, P.. 2011. Issues and Ethics in the Helping Professions Eighth Edition. Belmont USA: Brooks/Cole.

E. Beck, Carlton. 1971. Philosophical Guidelines for Counseling: The Place of Values in Counseling and psychotherapy, Iowa: WM.C. Brown Company Publishers.

Haolah, S., Atus, \& Irmayanti, R. (2018). Pentingnya Kualitas Pribadi Konselor Dalam $\begin{array}{lllll}\text { Pelaksanaan Konseling Individual. Fokus, } & \text { 1(6), }\end{array}$ http://www.elsevier.com/locate/scp

Handika, M., \& Herdi, H. (2021). Efektivitas Layanan E-Counseling dalam Membantu Permasalahan Siswa Selama Masa Pandemi Covid-19. Jurnal Paedagogy, 8(4), 506511. doi:https://doi.org/10.33394/jp.v8i4.3948

Haryadi, S. (2019). Korelasi Antara Kompetensi Profesional dan Multikultural Konselor Sekolah. Indonesian Journal of Learning Education and Counseling, 2(2), 124-129. https://doi.org/10.31960/ijolec.v2i2.219

Hunainah. (2016). Etika Profesi Bimbingan Konseling. 128.

Geldard, Kathryn \& Geldard, David, Keterampilan Praktik Konseling : Pendekatan Integratif, Alih bahasa Eva Hamidah, S.S. Yogyakarta: Pustaka Pelajar, 2005.

Gladding, T.Samuel. 2009. Counseling: A Comprehensive Profession. New Jersey: Pearson Education.Inc.

Gladding, T. Samuel,. (2012). Counseling: a Comprehensive Profession, sixth edition, alih 
bahasa P. M. Winarno \& Lilian Yuwono, Jakarta: PT. Indeks

Prakoso, E. T. (2008). Hubungan Profesional Konseling. Jurnal Inspirasi Pendidikan, 261272.

Putri, A. (2016). Pentingnya Kualitas Pribadi Konselor Dalam Konseling Untuk Membangun Hubungan Antar Konselor Dan Konseli. JBKI (Jurnal Bimbingan Konseling Indonesia), 1(1), 10. https://doi.org/10.26737/jbki.v1i1.99

Rakhmawati, I. (2013). Membangun Profesionalisme Guru Konseling Sekolah Melalui Penyampaian Bahasa Yang Santun. KONSELING RELIGI: Jurnal Bimbingan Konseling Islam, 4(2), 219-238.

Renatha Ernawati. (2020). BUKU MATERI PEMBELAJARAN PROFESIONALISASI BK (p. $38)$.

Sanyata, S. (2006). Perspektif Nilai Dalam Konseling : 02, 1-14.

Sari, M., \& Herdi, H. (2021). Cyber Counseling : Solusi Konseling di Masa Pandemi. Jurnal Paedagogy, 8(4), 579-585. doi:https://doi.org/10.33394/jp.v8i4.3949

Sodiq, D., \& Herdi, H. (2021). Pemanfaatan Teknologi Informasi Untuk Meningkatkan Kemampuan Perencanaan dan Kematangan Karir Siswa. Jurnal Paedagogy, 8(4), 540-544. doi:https://doi.org/10.33394/jp.v8i4.3951

Suharni, \& Christiana. (2020). PROFESIONALISASI BIMBINGAN DAN KONSELING (Asroful Kadafi (ed.)). UNIPMA Press (Anggota IKAPI).

Suherman, U. (2007). Kompetensi dan Aspek Etik Profesional Konselor Masa Depan. Educationist, 1(1), pp-39.

Supriatna, M. (2011). Bimbingan dan Konseling Berbasis Kompetensi (Orientasi Dasar Pengembangan Profesi Konselor. Jakarta: Raja Grafindo Persada.

Syah, Muhibbin 1995, Psikologi Pendidikan Suatu Pendekatan Baru, Bandung: PT. Remaja Rosdakarya Press.

Taher, Y., Husen, M., Aditama, R., Syam, S., Konseling, B., Pendidikan, F. I., \& Kunci, K. (2021). Profesionalisme guru bimbingan konseling.

Widada. (2019). PENINGKATAN PROFESIONAL GURU BIMBINGAN DAN KONSELING. Seminar Nasional Pendidikan PGSD UMS \& HDPGSDI Wilayah Jawa, 536-548.

Yusri, Fadhila. (2013). Perkembangan Profesional Konselor Untuk Memenuhi Kebutuhan Masyarakat Industri. Jurnal Konseling Dan Pendidikan, 1(1), 36. https://doi.org/10.29210/1700

Yusri, Fadhilla. (2019). Penguasaan Kompetensi Konselor Mahasiswa Peserta Program Pengalaman Lapangan (PPL) Prodi Bimbingan Konseling IAIN Bukittinggi. Jurnal Al-Taujih, 5(2). 